\title{
Consumo, sentidos, usos e apropriações nas pesquisas de recepção: nem tão sinônimos, nem tão distantes
}

\section{Daniela Maria Schmitz}

Doutora; Universidade Federal do Rio Grande do Sul danischmitz@ymail.com

\begin{abstract}
Resumo
$\mathrm{O}$ artigo discute as aproximações e especificidades das noções de consumo, sentidos, usos e apropriações, conceitos tão caros para os estudos do chamado campo da recepção, principalmente da vertente latino-americana. Na reflexão são incluídas ainda, as distinções entre recepção e consumo midiático. Toma-se por base as proposições de García Canclini e Martín-Barbero, amparando-se ainda em definições de dicionários de filosofia e sociologia. A intenção é contribuir para o debate com algumas acepções, sobreposições e contradições destes termos para apresentar uma proposta que os distinga enquanto processo de aquisição simbólica de produtos midiáticos.
\end{abstract}

\section{Palavras-chave}

Recepção. Consumo midiático. Uso (conceito). Sentido (conceito). Apropriação (conceito).

\section{Introdução}

O propósito aqui é discutir em primeiro plano o conceito de consumo (cultural e midiático), associando-o às noções de recepção, sentidos, usos e apropriações que são tão caros aos estudos das relações entre meios e audiências. A situação de tal área de investigação no Brasil, embora consolidada em termos quantitativos, ainda carece de discussões no âmbito teórico-metodológico (JACKS, 2014). Neste sentido, busca-se contribuir para o debate apresentando algumas definições e especificidades de tais noções, ainda que se entenda que muitos destes processos se sobreponham nas práticas dos sujeitos receptores, o que contribui para as imprecisões. Estas circundam a esfera dos estudos de audiência e já foram 
apontadas por Jacks e Escosteguy (2005, p.110) quando enunciam a prática comum de designar "[...] tudo ou quase tudo que gire em torno dos receptores [...] de estudos de recepção, independente do viés teórico implicado".

Assim, o artigo está estruturado de forma a discutir primeiramente a noção de consumo, pela perspectiva sociocultural de García Canclini (2006), e mais especificamente de consumo cultural e midiático, realizando contrapontos com o conceito de recepção para defender as especificidades de cada uma destas noções teóricas. Mais a frente focalizar-se-á os conceitos de usos, sentidos e apropriações, também comumente tomados como sinônimos de consumo, ou então ambos são utilizados para explicar um ao outro, sem que se aborde suas nuances.

A discussão é pautada por uma revisão teórica de autores-chave para os estudos de recepção latino-americanos, pela significação desses termos em dicionários de filosofia e sociologia e, também, por uma breve revisão do estado da arte dos estudos de consumo midiático brasileiros - teses e dissertações da área de Comunicação - na primeira década de 2000. Ao final, apresenta-se uma proposta de entendimento das noções aqui discutidas.

\section{Consumo cultural e midiático dentro da perspectiva sociocultural}

O consumo por muito tempo foi tomado como um produto direto da produção, assim como foi considerado um tema menor, cercado de preconceitos tanto em sua prática, como no seu estudo. Para Barbosa e Campbell (2009), toda a crítica e repúdio moral investido no consumo é revelador de uma visão idealizada de uma sociedade que prescindiria de relações materiais, como se os objetos não fossem mediadores das relações entre os sujeitos e o mundo ou como se os produtos não pudessem ser tomados como parte visível da cultura, como postula Douglas e Isherwood (2009).

Nas duas últimas décadas, o conceito passa por uma "redenção" acadêmica e torna-se foco de várias investigações e discussões que passaram a concebê-lo como fundamental para a reprodução social, sendo que a construção de subjetividades e identidades passaram a ser tratados quase como "sinônimos" de consumo (BARBOSA; CAMPBELL, 2009), o que aponta um novo status para o tema.

É dentro deste cenário mais favorável, mas ainda com uma carga bastante negativa associada ao fenômeno, que García Canclini, no início dos anos 1990, propõe a construção de uma teoria sociocultural do consumo. Sua perspectiva é bastante mobilizada nos estudos de recepção e consumo cultural, embora se defenda aqui tratarem-se de processos distintos. 
Sunkel (2006), ao abordar o desenvolvimento das reflexões sobre consumo nos estudos culturais latino-americanos, indica García Canclini e Martín-Barbero como signatários do segundo deslocamento teórico-metodológico que a temática sofreu. Se o primeiro, no início dos anos 1980, diz respeito a uma inversão em que o estudo da mensagem como estrutura ideológica desemboca nas pesquisas de recepção crítica ${ }^{1}$; o segundo movimento vai do estudo das culturas populares à recepção (ou ao consumo).

A proposta de García Canclini (2006) é ampliar o olhar sobre o ato de consumir, tomando-o como um espaço em que há reflexão e até mesmo reelaboração do sentido social: é "reconceitualizar o consumo, não como cenários de gastos inúteis e impulsos irracionais, mas como espaço que serve para pensar, e no qual se organiza grande parte da racionalidade econômica, sociopolítica e psicológica nas sociedades" (2005a, p.14). Defende, assim, a necessidade de investigar o fenômeno a partir de um aporte interdisciplinar e argumenta que, para os efeitos da construção de uma teoria, é preciso considerar que seu exercício se dá em condições socioeconômicas específicas.

No artigo seminal de sua proposta, publicado em 1991 - reeditado sob novo título em 1993 e revisitado em outros trabalhos ${ }^{2}$ - o autor traz alguns apontamentos sobre sua abordagem. De um modo sintético, o consumo seria "[...] um conjunto de processos socioculturais em que se realizam a apropriação e os usos dos produtos." (2006, p. 80, tradução nossa). Na defesa dessa sentença, há críticas e a superação de duas noções pelas quais o consumo por muito tempo foi explicado: a concepção naturalista das necessidades ${ }^{3} \mathrm{e}$ a instrumentalista dos bens ${ }^{4}$.

Em suas proposições, a autor aponta seis lógicas/racionalidades a partir das quais o fenômeno do consumo já foi estudado, as quais são aqui resumidas:

a) lugar de reprodução da força de trabalho e expansão do capital: parte da lógica econômica, com base marxista. Possui visão unidimensional, pois foca nas estratégias do mercado, no ciclo de produção e reprodução social;

b) cenário de disputas pela apropriação do produto social: parte da lógica sociopo-

\footnotetext{
${ }^{1}$ Sunkel (2006) cita Valerio Fuenzalida e Guilhermo Orozco Gomez como importantes expoentes nesse movimento.

${ }^{2}$ Como o de 2006 que é aqui utilizado como referência.

${ }^{3}$ Refuta a ideia de que existam necessidades naturais ou universais, ou ainda imutáveis, posto que mesmo as chamadas necessidades de ordem biológica, como a alimentação, são elaboradas a partir de uma série de práticas culturais, que são "[...] resultado da interiorização de determinações da sociedade e de elaboração psicossocial dos desejos." (2006, p. 79).

${ }^{4}$ Aqui se entende que os bens seriam produzidos com vistas ao seu valor de uso. Assim, um conjunto de bens seria criado para satisfazer um pacote de necessidades, numa correspondência mecânica ou naturalizada entre necessidades e objetos. A crítica a essa noção passa pela frequência com que o valor de troca se sobrepõe ao de uso, e também na existência de outras esferas de valor, como as simbólicas, implicadas tanto na produção, como na circulação e no uso dos bens.
} 
lítica interativa. Traz uma visão mais relacional, enfocando a interação entre oferta e demanda; é aqui que as estratégias diferenciadas de aquisição e utilização dos bens ganham espaço, ou seja, está inscrita no cotidiano e é o espaço em que se constrói a cidadania;

c) lugar de diferenciação social e distinção simbólica entre classes: parte da lógica consumidora, com base nos estudos de Bourdieu. Tem foco na dinâmica de distinção social buscada a partir do consumo, na qual a diferenciação é o motor da economia dos bens simbólicos. Jacks (1996) pontua que, embora Bourdieu trate dessa dinâmica desde o ângulo das elites, essa distinção também pode ser buscada nas classes populares;

d) sistema de integração e comunicação: de lógica integrativa, foca no consumo como integrador de classe. É um contraponto à lógica anterior, embora não desconsidere os elementos de distinção inscritos no ato de consumir, porém, pressupõe que, para que a distinção se opere, é preciso haver um compartilhamento de sentidos a respeito;

e) processo ritual: parte da lógica ritualística, evidenciando os aspectos de rito inscritos no consumo, explorando sua organização/operação. Com base na perspectiva antropológica de Douglas e Isherwood (2009), os rituais são vistos como uma forma de conter a flutuação a que os significados estão sujeitos, sendo que o consumo dá significado aos objetos, o que contribui para dar sentido à ordem social;

f) cenário de objetivação de desejos: parte de uma lógica irracional, concebe o consumo como fruto do desejo, que está para além das necessidades, e que não pode ser satisfeito pelas instituições. De difícil apreensão empírica, mas serve para pontuar que o consumo também opera em outra gramática não acionada pelo consciente.

O olhar transversal que García Canclini reivindica que seja lançado ao fenômeno do consumo deveria articular as seis lógicas supracitadas. Nessa concepção integral, que parte de uma racionalidade intercultural, o autor de certa forma incorpora a ideia de intersecção, cruzamento, articulação, mescla, conflito e contradição que já explicava o conceito de hibridação (2003) pelo qual é bastante conhecido. Ao longo de seus escritos, vê-se um rompimento com a dicotomia analítica e a proposição de um olhar de análise que parte do "entre". 
Contudo, incorporar a mirada transdisciplinar reivindicada por ele não se coloca como tarefa fácil, uma vez que o próprio autor aponta as dificuldades de se estabelecer princípios teóricos e metodológicos transversais para abarcar os seis caminhos pelos quais o consumo já foi e ainda é pensado.

A abordagem de García Canclini (2006) também concebe que todo o consumo é cultural, pois o ato de adquirir qualquer bem é muito mais amplo do que a ação de posse. Independente do que se consuma, o processo inclui distinção simbólica, assim como integra e comunica, objetiva desejos e ritualiza a satisfação. Sendo assim, soa estranho distinguir consumo de consumo cultural - empregado no caso de determinados bens ou atividades, principalmente nas artes e nas ciências. Mas é o próprio autor quem defende tal divisão, pois entende que a autonomia dos campos artísticos e intelectuais na modernidade acabou criando circuitos independentes para produção e circulação da arte, literatura e conhecimento. E, para o autor:

Os produtos denominados culturais têm valor de uso e troca, contribuem para a reprodução da sociedade e às vezes para a expansão de capital, porém neles os valores simbólicos prevalecem sobre os utilitários e mercantis. (GARCIA CANCLINI, 2006, p. 88, tradução nossa).

Mais à frente, no mesmo texto, o autor é ainda mais taxativo em sua definição, quando reitera que trata-se de cultural quando o simbólico tem primazia sobre os valores de uso ou troca, "ou ao menos estes últimos se configuram subordinados à dimensão simbólica". (GARCIA CANCLINI, 2006, p. 89, tradução nossa).

Sobre o consumo midiático, García Canclini (2006) percebe algumas especificidades, principalmente em relação à maior implicação econômica, mas sustenta que muito embora as exigências e a sujeição ao financeiro interfiram na produção, estilo e circulação dos produtos midiáticos, eles possuem uma determinada autonomia que diz respeito à dinâmica própria de seus processos produtivos e seu consumo, o que torna possível tomá-los como bens culturais. E a própria contextualização sobre consumo cultural permite pensar sobre a oferta midiática como uma vertente dele.

Embora os estudos de recepção e consumo sejam correntes no país há mais de 20 anos - vide os estudos sobre o estado da arte de Jacks (et al. 2008; 2014) - pouco se discute sobre as especificidades do consumo midiático. Toaldo e Jacks ponderam que se trata:

[...] do consumo do que a mídia oferece: nos grandes meios - televisão, rádio, jornal, revista, internet, sites, blogs, celulares, tablets, outdoors, painéis ... - e nos produtos/conteúdos oferecidos por esses meios - novelas, filmes, notícias, informações, entretenimentos, relacionamentos, moda, shows, es- 
petáculos, publicidade, entre outros. Neste contexto, a oferta da mídia inclui também o próprio estímulo ao consumo, que se dá tanto através da oferta de bens (por meio do comércio eletrônico e da publicidade), quanto no que se refere a tendências, comportamentos, novidades, identidades, fantasias, desejos... (2013, p. 6-7)

Outros autores ajudam a sustentar a adoção de consumo midiático para designar um tipo específico de consumo, visto a crescente participação e importância da mídia na configuração da sociedade contemporânea. Rodrigues (2000) defende que o midiático encarna um papel estratégico, com cada vez maior autonomização em termos de campo social. Silverstone argumenta que "Nossa mídia é onipresente, diária, uma dimensão essencial de nossa experiência contemporânea." (2002, p. 12)5. Carrascoza e Rocha (2011) dão a esse processo um status pouco comum, uma vez que enumeram três tipos de consumo: material, simbólico e midiático. 0 midiático tradicionalmente fora tomado como consumo simbólico, por se tratar de um produto da indústria cultural, mas defende-se aqui que se trata de um tipo específico de consumo cultural, com algumas particularidades em relação aos processos de recepção, distinções tratadas na sequência.

\section{Consumo midiático $X$ recepção}

Mesmo que recepção e consumo midiático estejam muito próximos como práticas inscritas no âmbito da audiência, entende-se que se tratam de processos distintos. As aproximações podem ser justificadas, principalmente em trabalhos empíricos, pois ambos demandam a "captação das práticas/formas culturais em fonte primária" (RONSINI, 2010, p. 3). Contudo, segue-se o rastro já deixado por outros autores para demarcar as distinções, e analisa-se os trabalhos empíricos de consumo midiático concluídos na primeira década dos anos 2000, com vistas a buscar suas especificidades em relação aos estudos de recepção.

Cabe iniciar com a argumentação de Martín-Barbero (2006), quando indica que o deslocamento do conceito de recepção à noção de consumo cultural passou por alguns malentendidos: sua associação com a medição de audiência, no caso da recepção de TV enquanto consumo cultural fixou os estudos num viés quantitativo, assim como padeceu de um reducionismo economicista que identifica o consumo como liberdade de opção. Esse movimento se deu em função da falta de questionamentos sobre as razões sociais e culturais que geram regularidades de conduta e também o tipo de relação que se estabelece com os meios

\footnotetext{
5 Embora não adote o termo "midiático", os trabalhos recentes de Martín-Barbero também discutem o protagonismo do comunicativo ou da mediação da tecnicidade nos processos de consumo e recepção. A discussão sobre midiatização também aponta para a centralidade da mídia e a produção de Braga, Verón e Fausto Neto são referências.
} 
de comunicação. Entende-se aqui que um estudo do consumo cultural ou midiático possa se valer ou partir de dados quantitativos, mas a abordagem sociocultural ultrapassa a reprodução de dados acerca do "que" ou do "quando" se consome.

Como já se apontou, no Brasil, desde a emergência dos estudos sobre as relações dos sujeitos com os meios, principalmente a partir da vertente da teoria das mediações (MARTÍN-BARBERO, 2003), designou-se esse campo de investigação como "estudos de recepção" de uma forma ampla. Porém, ainda na década de 1990, alguns pesquisadores já operam uma divisão entre as perspectivas do consumo, filiada a García Canclini, e a dos usos sociais, a Martín-Barbero, como é o caso de Jacks (1996).

Para Jacks e Escosteguy (2005) a proposta de consumo cultural de García Canclini, confrontada com a teoria dos usos sociais de Martín-Barbero, está mais em sintonia com uma tradição sociológica, num caráter mais macro de análise, calcada no uso de técnicas de padronização de dados, enquanto a proposta "barberiana" está mais centrada no exame dos processos de recepção midiática propriamente ditos, focalizando mais a produção de sentido, num nível mais micro. Contudo, os próprios autores não se ocupam de tal distinção e, como destaca Ronsini (2013), ambos utilizam os dois termos para se referir ao mesmo processo. A autora recorda que Martín-Barbero já tratou da recepção como uma análise integral do consumo, enquanto Canclini raramente refere-se à recepção, e supõe que essa omissão se deva à quase inexistência deste tipo de pesquisa em seus estudos empíricos.

Para avançar nas distinções, traz-se a observação de García Canclini e Rosas Mantecon (2005b) que destacam que uma perspectiva mais atual de consumo cultural é tomada para além da compreensão da recepção de um produto particular, mas como o conjunto de processos que condicionam e atravessam esta recepção. Assume-se também o argumento de Ronsini (2007) que, baseada em Leal (1995), propõe que um estudo de recepção preocupase em reconstruir como uma determinada mensagem de um produto midiático é decodificada, compreendida e vivenciada por um grupo de pessoas, enquanto no consumo de mídia o foco não estaria na apropriação de programas ou gêneros específicos, mas no entendimento do sentido geral das tecnologias da comunicação e na experiência vivida pelo receptor em seu cotidiano.

Essas concepções também vão ao encontro do que propuseram Toaldo e Jacks (2013) quando ponderam que um estudo do consumo midiático observa o fenômeno sob um ângulo mais amplo que a pesquisa de recepção “[...] justamente porque tem o foco direcionado para a relação com os meios e não com as mensagens, para usar uma imagem simplificada do 
processo." (2013, p. 7-8).

A discussão de Lozano (1991), embora centrada na trajetória dos estudos de recepção nos Estados Unidos, também segue nesta linha. 0 contraponto da autora é entre a noção de audiência - que aqui poder-se-ia associar à recepção - e a de consumo. Para ela, o conceito de consumo é mais adequado, pois a noção de audiência é fundada em discursos finitos, coerentes, interpretáveis e isoláveis. Parte da ideia de que um estudo de recepção "descola" um determinado produto de uma grade de programação (no caso da televisão) para investigar os sentidos ali produzidos. E, quando sugere que o consumo seja uma noção mais adequada, defende sua proposta a partir de Baudrillard, cuja ideia de consumo reside na multiplicidade, simultaneidade e intermitência e pontua que:

As audiências estão dispersas, o sujeito social é um "viajante", negociante/em trânsito, que descansa aqui e ali, que escuta notícias entrecortadas e lembra lugares que nunca visitou e visita lugares que não pode lembrar. (LOZANO, 1991, p. 2, tradução nossa).

Sua argumentação traz à tona a noção de consumidores errantes e defende que o foco das pesquisas deva centrar-se nas práticas cotidianas, o que há muito é postulado por De Certeau (2007) e reforçado por Martín-Barbero $(2003,2006)$ em sua defesa de um olhar investigativo sobre a cultura comunicativa.

Mesmo trazendo autores pertinentes à discussão sobre as distinções entre consumo cultural (midiático) e recepção, admite-se que não há consenso na área sobre o tema e nem mesmo uma ampla discussão a respeito. E, para contribuir de forma mais concreta com essa reflexão, lançou-se um olhar sobre a produção discente em pós-graduação na primeira década dos anos 2000, dentro da área da Comunicação. Com base nos dados da pesquisa coordenada por Jacks (2014) sobre o estado da arte das investigações empíricas sobre recepção e consumo, faz-se um levantamento das regularidades e particularidades das pesquisas que se autodenominam "de consumo" (quando o título já deixa claro essa filiação) ou ainda das pesquisas cujas palavras-chave contenham tal expressão. Embora essa revisão pareça restrita às práticas de pesquisadores mais novatos, entende-se que este olhar sobre a produção discente é relevante porque indica também o posicionamento de pesquisadores mais experientes que orientaram tais investigações. Assim, intenta-se avançar nas distinções desses dois tipos de estudo com base na prática investigativa recente.

Entre 2000 e 2009, tem-se 209 teses e dissertações defendidas na área da Comunica- 
ção que tratam do âmbito da audiência dos meios. Deste total, 30 trabalhos $^{6}$ (14\%) usam o termo consumo no título ou nas palavras-chave, sendo que apenas 18 (9\%) assumem isso no próprio título. 0 que se pode depreender desses números é que ainda há uma primazia das pesquisas de recepção, ou que ainda não se tenha uma preocupação maior em diferenciar essas duas perspectivas. Assim, recepção e consumo seguem sendo tomadas uma pela outra, ou melhor, tudo leva a crer que ainda adota-se "recepção" como sinônimo de pesquisa no âmbito da audiência, já que nas análises realizadas pelo grupo de pesquisadores coordenado por Jacks (2014), há trabalhos classificados como sendo de consumo, mesmo que não se auto intitulem.

Acerca do nível das pesquisas, os números são próximos: entre as que se enunciam como investigações sobre consumo midiático, cinco são teses (17\%) e 25 dissertações (83\%). Nos demais trabalhos, 44 teses (25\%) e 135 dissertações (75\%). Tais indicativos levam a pensar que o prazo para execução ou a experiência do pesquisador não sejam determinantes para a opção por um estudo de consumo midiático ou de recepção.

Sobre os meios mais investigados, no conjunto de trabalhos sobre consumo: oito pesquisas (27\%) são sobre mídia em geral, 14 (47\%) sobre TV e seis (20\%) sobre internet. Nas demais investigações, nove pesquisas (5\%) sobre mídia em geral, 98 (55\%) sobre TV e 25 (14\%) sobre internet. Aqui talvez residam as maiores discrepâncias entre as duas perspectivas, ajudando a configurar o que caracterizaria cada uma delas. As investigações sobre a mídia em geral estão bem mais presentes nos estudos de consumo, o que pode indicar que estes não efetuam um recorte focado em um meio, mas no atravessamento deles na experiência de consumir. Nesse item também sobressai um alto número de pesquisas dedicadas à televisão. Contudo, o meio TV é, no total das pesquisas, o mais estudado. Já os estudos de internet estão mais presentes no conjunto de investigações sobre consumo, ainda que não haja uma diferença tão acentuada. Infere-se que isso ocorra por este meio remeter à interação, sendo, portanto, pouco usual o termo "recepção de internet", uma vez que a expressão ainda carrega em si um forte sentido de "receber" que pode estar associado à passividade o que não está de acordo com a concepção de recepção aqui adotada.

Na comparação entre os gêneros investigados, nas pesquisas de consumo nove (30\%) são sobre nenhum ou vários gêneros e 10 (33\%) sobre publicidade. Nas demais investigações, 42 pesquisas (23\%) sobre nenhum ou vários gêneros e $11(6 \%)$ sobre publicidade. Embora a diferença não seja tão gritante, aqui se repete a ideia de que as pesquisas sobre

\footnotetext{
${ }^{6}$ Em função dos limites deste artigo e do tamanho do corpus analisado, os trabalhos não serão indicados nas referências.
} 
consumo trabalham com um recorte pluri, não estando focadas em um único gênero para análise. Os estudos sobre publicidade também obtiveram destaque no bloco relativo ao consumo. Isso pode ser explicado pelo fato de que, por si só, o termo publicidade remete ao fenômeno, uma vez que o material publicitário é criado com vistas a estimular o consumo material e simbólico.

Em se tratando dos programas/veículos investigados, nas pesquisas sobre consumo, 17 (57\%) não recortam a análise em nenhum programa ou veículo em especial. Nas demais, o mesmo ocorre em 41 trabalhos (23\%). Mais uma vez tem-se dados que ajudam a defender a ideia de que os estudos de consumo trabalham com uma audiência atravessada por várias fontes, no caso aqui referido, de vários programas ou veículos.

Tomando por base este apanhado geral das pesquisas que se intitulam como sendo de consumo na primeira década de 2000 e dentro do que foi exposto a partir dos autores citados, faz-se algumas considerações e inferências sobre as especificidades das pesquisas sobre consumo e recepção. Entende-se que uma investigação de consumo midiático distingue-se de um trabalho de recepção pela natureza da pergunta que os orienta. Embora possam ser pensados de forma complementar, um trabalho sobre o consumo sugere um olhar mais amplo, de orientação transversal em relação à totalidade de conteúdos midiáticos que se consome, podendo-se também recortar em um meio ou uma temática, por exemplo.

Já a pesquisa de recepção vai dar conta de um gênero ou produto midiático específico, realizando um recorte que possibilite a captação e aprofundamento dos sentidos produzidos a partir de sua audiência. Pode adquirir uma orientação horizontal se a problemática a ser investigada envolver o relacionamento com o produto em nível sincrônico, mas entende-se que esse tipo de estudo requer uma circunscrição maior que uma investigação do consumo, em que os sentidos produzidos se constroem justamente na sobreposição de conteúdos, criando mosaicos nos quais se tecem os sentidos. Atenta-se ao fato que o entendimento aqui é de que a produção de sentidos não é restrita ao momento da recepção ou do consumo, o que complexifica ainda mais esse tipo de estudo. E é preciso ter em mente que, mesmo nas pesquisas de recepção, cuja circunscrição em relação à mensagem midiática é maior, o sentido se constrói em um determinado fluxo de consumo. É dentro deste fluxo que formam-se os palimpsestos que contribuem para a produção de sentidos. A noção de palimpsestos é apropriada de Martín-Barbero e Rey (2001), e originalmente é associada ao âmbito da produção, mais especificamente ao emaranhado de gêneros que se constitui a TV. Para os autores, palimpsesto é associado à memória inscrita em cada produto textual e à pluralidade de tem- 
pos, e pode ser tomado como "o texto no qual um passado apagado emerge tenazmente, embora imprecisamente, nas entrelinhas escritas pelo presente" (2001, p. 63). Entretanto, compreende-se que a noção possa ser trabalhada desde a perspectiva do consumo, em que os palimpsestos são considerados como a trama de textos provenientes das fontes mais diversas (midiáticas ou não) que se cruzam nos processos de consumo, marcando a produção de sentidos e os usos realizados.

Por fim, Ronsini, ao traçar um paralelo entre as duas perspectivas, aponta algumas particularidades do consumo em relação à recepção:

\begin{abstract}
a) existe aí uma pluralidade de textos e não um texto específico para ser decifrado; b) não há preocupação em considerar teoricamente as mediações que constituem o processo de dar sentido à mídia e tampouco os detalhes empíricos que envolvem o conhecimento do papel delas; c) o consumo é a interpretação que o investigador faz das práticas do investigado, isto é, do uso dos bens na rotina de quem usufrui deles e, em menor medida, se caracteriza pela dupla hermenêutica da recepção, a de interpretar a interpretação do investigado. (2010, p. 3).
\end{abstract}

Concorda-se com a argumentação da autora nos dois primeiros pontos, porém, não compartilha-se inteiramente da aproximação que faz entre consumo e usos no item 'c', pois pretende-se defender aqui que a noção de uso passa muito mais pelas práticas de produção de sentido do que pelo ato de consumir em si, o que se expõe na sequência.

\title{
4 Consumo, usos, sentidos e apropriações
}

A maioria dos estudos de recepção e consumo está interessada nos usos, sentidos e apropriações que são operadas a partir da oferta midiática. E aqui, mais uma vez não há consenso nem discussão sobre o que caracterizaria ou distinguiria cada um destes processos. Dessa forma, tenta-se demarcar algumas nuances que possam indicar singularidades, ainda que não seja tarefa fácil. A pouca discussão acerca das peculiaridades de cada um desses conceitos e a ampla gama de processos abarcados pelo consumo dificulta ainda mais sua problematização teórica. Somado a isso, Barbosa e Campbell $(2009$, p. 23) alertam que, com a emergência dos estudos sobre a temática nos últimos vinte e cinco anos, processos da vida social como "[...] o uso, a fruição, a ressignificação de bens e serviços, que sempre corresponderam a experiências culturais percebidas como ontologicamente distintas, foram agrupados sob o rótulo de 'consumo' e interpretados sob esse ângulo".

Retomando a definição de García Canclini para sua abordagem do consumo, este seria “[...] um conjunto de processos socioculturais em que se realizam a apropriação e os usos 
dos produtos." (2006, p. 80). Assim, pode-se dizer que o autor vê distinções entre os termos “consumo, apropriação e usos", embora não as discuta. No mesmo texto, revela certo desconforto com o vocábulo "consumo", em função do caráter economicista do qual está impregnado, porém, mesmo insuficiente para dar conta de sua proposta plural, considera o termo mais adequado do que recepção, apropriação, audiência ou usos. E entende-se, mesmo com o pouco que o autor acaba discutindo a esse respeito, que dentro do consumo estariam contidas estas demais noções/operações.

Para subsidiar a discussão das distinções, além da revisão de autores-chave dos estudos latino-americanos de recepção e consumo, buscou-se definições em dicionários de sociologia e filosofia. Porém, a busca não foi profícua, visto que de doze obras consultadas oito dicionários de filosofia e quatro de sociologia - apenas um trouxe o verbete "consumo", e o faz a partir de uma perspectiva economicista: "[...] uso consuntivo de bens e serviços para a satisfação das necessidades humanas." (FAIRCHILD, 1949, p. 65, tradução nossa).

Algumas pistas sobre as distinções desses termos podem ser encontradas em entrevista de García Canclini à publicação Caderno de Leitura, da EDUSP ([2008]). Ao ser questionado sobre como diferenciar consumo de cultura, responde que:

No campo da cultura falamos de consumo, mas também de apropriação, para nos referirmos ao caráter ativo e a possíveis reapropriações e modificações que o consumidor pode fazer ao receber um programa de televisão, ler um romance, ou relacionar-se com uma mensagem na Internet.

A partir disso, pode-se supor que esteja se referindo a apropriação, reapropriações e modificações como ações que ocorrem a partir do consumo, ou seja, operações desencadeadas pelo processo de consumir ou até mesmo posteriores a ele.

Parte-se desse entendimento para problematizar a perspectiva do autor, pois compreende-se que o consumo cultural/midiático esteja focado nos processos (como, quando, onde) em que se consome e principalmente no que é consumido (material e simbolicamente), numa mirada sobre os hábitos, tipos, formas e conteúdos adquiridos. Por outro lado, compreende-se que o conceito de usos está mais voltado a uma ação, atitude, remanejo, emprego, posicionamento e até mesmo a aceitação em relação ao que é consumido. Enfim, a noção de usos, no entendimento que se constrói aqui, passa pela produção de sentidos inscrita tanto no consumo quanto nos próprios usos, pois é só a partir dela que é possível posicionar-se a respeito do que se consome. Dessa forma, o uso seria 
uma operação sobre e a partir do que se adquire e estas operações podem se configurar como apropriações, aceitações, imitações, rejeições ou até mesmo outros tipos de usos.

Para sustentar a argumentação desta proposta, traz-se, em primeiro lugar, a discussão acerca do consumo que nos coloca Martín-Barbero:

O consumo não é apenas reprodução de forças, mas também produção de sentidos: lugar de uma luta que não se restringe à posse dos objetos, pois passa ainda mais decisivamente pelos usos que lhes dão forma social e nos quais se inscrevem demandas e dispositivos de ação provenientes de diversas competências culturais. (2003, p. 302).

Entende-se, pelo que coloca o autor, que a partir do consumo é possível atribuir sentido e dar usos sociais aos objetos. Sua proposição aproxima "uso" de "ação", corroborando para a noção de operação a partir do consumo que se defende aqui. MartínBarbero também condiciona e tensiona essa ação a partir de uma das mediações com que trabalha, a competência cultural, o que pressupõe o exame mais detalhado da fabricação de sentidos do sujeito, associada às suas experiências e vivências culturais que condicionam tanto os usos como os sentidos configurados.

Seguindo na definição de "usos", nos oito dicionários de filosofia consultados7, apenas três trazem a noção, sendo que todos discutem o termo associando a significação ao uso, condicionando a primeira às formas a partir das quais "se usa". As três obras citam a "filosofia tardia"8 de Wittgenstein para discutir o verbete:

USO (in. Use; fr. Usage; al. Gehrauch; it. Uso). 0 ato ou o modo de empregar meios, instrumentos ou utensílios.

$[\cdots]$

Wittgenstein lançou mão da noção de U. para definir o significado dos termos lingüísticos: "Para uma ampla classe de casos - embora não para todos - nos quais empregamos a palavra 'significado', ela pode ser assim definida: o significado de uma palavra é o seu U. na linguagem" (ABAGNANO, 1998, p. 985).

Embora a citação refira-se mais ao emprego da língua, a perspectiva de significação condicionada ao uso se faz presente. Na obra a seguir, a associação se mantém, trazendo à discussão a necessidade de compreender as lógicas do uso:

USO.

$[\cdots]$

\footnotetext{
${ }^{7}$ Consultou-se também alguns dicionários de sociologia, nos quais o termo não foi encontrado.

${ }^{8}$ Segundo Scruton (1982), o filósofo teve sua produção intelectual dividida em dois momentos, e a segunda fase de seu pensamento é conhecida como tardia. Disponível em: http://www.cfh.ufsc.br/ mafkfil/scruton.htm. Acesso em: 03/08/14.
} 


\begin{abstract}
“Não questionar sobre a significação, questionar sobre o uso." Trata-se de averiguar quais são os usos de termos como 'ser', 'saber', 'verdade', 'poder', 'causar', 'parecer', etc., que desempenham um papel central nas discussões filosóficas e que, segundo esses pensadores, são geralmente mal entendidos porque não se examinam os seus usos, quer dizer, sua "lógica". [...] (MORA, 1998, p. 3619, tradução nossa) 9 .
\end{abstract}

Mora (1998) também traz a perspectiva do filósofo espanhol Ortega y Gasset, na qual é possível perceber a proposta de ação, de manifestação, de operação a partir do uso. 0 termo pressupõe um fazer que pode ser relacionado tanto à adoção ou protesto dentro do sistema de usos em que vivem os sujeitos, destacando que os usos têm caráter histórico. Nas próprias palavras de Mora:

[...] no pensamento de Ortega e Gasset, 'uso' é um termo que designa o modo fundamental de manifestar-se da sociedade humana. Os usos são atos humanos que podem caracterizar-se por sua impessoalidade: uso é na verdade, o que é feito. 0 indivíduo vive dentro de um sistema de usos aos quais se adere ou contra os quais se protesta, mas que não se pode deixar de ter em conta. [...] Sem usos seria impossível viver, porque o indivíduo não pode fazer tudo por si só. Mas ao mesmo tempo em que facilitam a vida individual, os usos a oprimem. Esta opressão adquire grandes proporções quando os usos já não são vigentes. Os usos são, portanto, também de caráter histórico. (1998, p. 3620, tradução nossa, grifo nosso) ${ }^{10}$.

Como já foi dito, na argumentação de Mora, fica explícita a associação entre uso e ação. Sua perspectiva de uso ainda prevê uma tomada de posição do sujeito em relação ao que ele utiliza. E, retomando a proposta que se discute, esse posicionamento dos sujeitos passa pela produção de sentidos, que pode ajudar a "moldar" os usos que são atribuídos aos produtos culturais e midiáticos.

Martín-Barbero (2003, p. 312) aborda as lógicas dos usos, conforme enuncia, desde o campo da cultura: "dos conflitos articulados pela cultura, das mestiçagens que a tecem e dos anacronismos que a sustentam" (grifos do autor). Com isso, defende a necessidade de um distanciamento da proposta dos "usos e gratificações", corrente na academia no período prévio ao lançamento da obra "Dos meios às mediações", de 1987, quando a preocupação girava em torno das mensagens que circulavam, das reações e efeitos que causavam. Na

\footnotetext{
${ }^{9}$ No original: "No inquirir por la significación; inquirir por el uso." Se trata de averiguar cuáles son los usos de términos como 'sé', 'sabe', 'verdad', 'puedo', 'causa', 'parece', etc., que desempeñan um papel central em las discusiones filosóficas y que, según dichos pensadores, son generalmente mal entendidos porque no se examinan sus usos, es decir, su “lógica”. [...] (MORA, 1998, p. 3619).

${ }^{10}$ No original: [...] en el pensamiento de Ortega y Gasset, 'uso' és un termino que designa el modo fundamental de manifestarse la sociedade humana. Los usos son actos humanos que pueden caracterizarse por su impersonalidad: uso es en efecto, lo que se hace. El individuo vive dentro de un sistema de usos a los cuales se atiene o contra los cuales protesta, pero que no puede dejar de tener en cuenta. [...] Sín usos seria imposible vivir, porque el individuo no puede hacerlo todo por sí mismo. Pero a la vez que facilitan la vida individual, los usos la oprimen. Esta opresión alcanza proporciones máximas cuando los usos no son ya vigentes. Los usos son, pues, também, de carácter histórico. (1998, p. 3620, grifo nosso).
} 
discussão de Martín-Barbero (2003) as lógicas dos usos não se esgotam nas diferenças inscritas desde a classe social, mas defende também que essa diferença articula outras, já que os usos dos meios são atravessados pelos habitus de classe, referindo-se à noção cunhada por Bourdieu. Expõe também que a competência cultural se inscreve na lógica dos usos, atravessando as classes. Referindo-se a um trabalho de Carlos Monsiváis sobre a cultura popular urbana no México, Martín-Barbero (2003) usa os termos do autor para tratar da questão da dinâmica dos usos, enunciando que é preciso ter em conta a maneira como as coletividades "assimilam as ofertas a seu alcance" (2003, p. 281, grifos do autor).

Deste modo, pensa-se com Martín-Barbero (2003) que os usos são inseparáveis da situação sociocultural do receptor e, com De Certeau (2007), que nestes usos se expressam potenciais de apropriação, o que possibilita levar em conta o que os sujeitos "fazem com" as informações obtidas na mídia, fabricando sentidos que muitas vezes podem ser desviantes e que são configurados a partir de referências das práticas cotidianas, situadas em contextos socioculturais específicos. Como discute Martín-Barbero (2006), os usos falam para além da situação de classe, referem-se às competências culturais que atravessam as posições econômicas seja pela educação formal, mas também pelos saberes construídos a partir da etnia e da cultura local.

A noção de apropriação de De Certeau (2007) também é útil para a discussão, pois além de enfocar as processualidades do consumo, trabalha com a perspectiva de ação dos sujeitos sobre o que é consumido: ele toma algo para si, a partir de referências próprias. Para o autor, o consumo é configurado segundo interesses e regras próprias do receptor, é uma operação astuciosa, dispersa, silenciosa, invisível, que não se faz notar por produtos próprios, não possui materialidade, mas está inscrito nas maneiras de empregá-los, ou seja, nos seus usos. E o conceito de apropriação é tomado aqui como um tipo de uso, tal qual se considera copiar, rejeitar e aceitar a oferta midiática. Contudo, no ato de apropriar-se reside a ideia de reelaboração/modificação que não se faz presente nos demais usos citados.

Para concluir, uma breve explanação sobre a noção de sentidos, deixando claro que se entende que sua produção acompanha todos os processos aqui discutidos, pois ela se dá tanto no ato do consumo e da recepção, quanto nos usos que são operados a partir destes.

Martín-Barbero (1990) entende que o sentido está inscrito na fabricação dos sujeitos. Para o autor, a análise do discurso dos meios leva ao entendimento da significação que, embora importante, não dá conta do processo de produção de sentidos: 
[...] para poder falar do sentido da comunicação é preciso falar do sentido que a comunicação tem para as pessoas. 0 sentido é sempre a relação de um texto com uma situação, com alguns enunciadores em um contexto temporal e espacial. (MARTÍN-BARBERO, 1990, p. 36, tradução nossa).

0 autor trabalha a problemática dos sentidos dentro do conceito de mediação social (2003), no qual concebe uma interação entre estruturas e dinâmicas socioculturais para emersão dos sentidos fabricados via consumo e recepção de produtos midiáticos. As muitas instâncias que interagem nesse processo criam um variado sistema de trocas que se afasta de uma ideia de verticalidade na comunicação, na qual o receptor seria dependente ou manipulável.

Outro autor que ajuda a pensar a noção de sentidos, ainda que bastante vinculado à problemática dos discursos, é Verón (1980). Ele concebe a produção de sentidos em um outro âmbito, no qual estariam implicados a produção, a circulação e o consumo, sem vincularse a nenhum deles em específico. Para Verón, as matérias significantes - os produtos midiáticos - trariam consigo uma série de traços constitutivos de seu sistema produtivo, este concebido a partir de relações articuladas entre a produção, a circulação e o consumo. Sendo assim, seria no "espaço" entre os dois polos produtores de discursos, a produção e o reconhecimento - forma como o autor prefere referir-se ao consumo elaborado pela recepção - cada qual com suas especificidades e "gramáticas", que se constituiria o sentido. Um sentido que jamais seria único pois, para além de uma relação uniforme, os desacordos entre produção e reconhecimento seriam geradores de um campo de efeitos de sentido que abre espaço para a complexidade das regras de produção e para os distintos conjuntos culturais presentes na recepção.

Entretanto, ainda que a proposta de Verón abra espaço para a cultura e as práticas dos sujeitos, há uma grande valorização das marcas discursivas dos produtos midiáticos, mesmo que o receptor, pelo seu entendimento, esteja ali contido. Deste modo, é Martín-Barbero (1990) quem efetivamente defende a ida até o receptor para uma investigação dos usos e sentidos do comunicacional: para poder dar conta integralmente da significação inscrita nas mensagens, é preciso ver quem responde e o que se faz a partir dela, ou seja, as práticas dos sujeitos adquirem um primeiro plano. 


\section{Concluindo com o início de uma proposta}

O que se tentou empreender aqui foi uma discussão acerca de conceitos bastante caros aos estudos de audiências. Longe de esgotar a questão, e com clara filiação aos estudos culturais latino-americanos, este artigo afina-se com a perspectiva sociocultural do consumo de García Canclini. Uma proposta integrativa e transdisciplinar para pensar os processos de aquisição de bens simbólicos, aqui cunhados de consumo cultural e midiático. Defende-se a adoção deste último para denominar as investigações que dão conta de entender o que os indivíduos consomem na mídia, as práticas envolvidas no processo, os usos e sentidos fabricados a partir deste consumo que não está circunscrito a um programa ou veículo específico. E, principalmente, os trabalhos que focalizam um atravessamento plurimidiático no cotidiano dos sujeitos para tratar de uma determinada problemática no âmbito das audiências deveriam estar agrupados em torno da insígnia do consumo midiático.

Sobre a noção de usos, tem-se o entendimento que estes passam e são determinados pela produção de sentidos, pois é a partir da elaboração e compreensão particular, inscrita na fabricação dos sujeitos, que os usos são modelados e colocados em prática no contexto social. Parte-se da ideia de que o uso seria uma operação sobre e a partir do que se consome e pode se valer de distintas operações: desde uma apropriação em que há remanejo/reelaboração partindo de referências do próprio indivíduo, até imitações de modelos de comportamento/aparência midiatizados, para exemplificar. Contudo, esta imitação foi determinada por uma produção de sentidos positiva e favorável à aceitação daquelas figuras. Ou seja, é a partir dos sentidos mobilizados que opera-se o posicionamento e o uso do que se consome.

Deste modo, entende-se que seria possível pensar que existam três "etapas" na relação indivíduo-mídias: consumo, sentidos e usos, e há uma necessidade pungente de melhor discuti-las e caracterizá-las para abordar o consumo midiático, ou mesmo a recepção dos meios, que seria um consumo circunscrito a determinado tipo de mensagem midiática. Longe de propor aqui uma estrutura funcionalista, não se sugere que existam três fases totalmente distintas no processo ou que elas tenham que ser efetuadas apenas na ordem acima apresentada. Há sim um imbricamento das três no processo, o que dificulta sua apreensão empírica, mas que de todo modo não pode ser descartada, considerando principalmente as investigações que enfocam as práticas dos sujeitos consumidores. Mesmo 
propondo tal ordenamento, entende-se também que os usos podem ser geradores de novos sentidos, pois estes sempre são elaborados e reelaborados socialmente.

Por fim, entende-se que tal proposição está de acordo com a discussão de Hall, no clássico capítulo Codificação/Decodificação de 1973. Isso porque o autor concebe que anteriormente ao uso que se dá a determinada mensagem, ela "deve primeiro ser apropriada como um discurso significativo e ser significativamente decodificada" (2011, p. 368). Contudo, a terminologia empregada por Hall é bastante centrada nos estudos do discurso e, tomando por base o que se discutiu aqui, tal proposição poderia ser reelaborada entendendo a apropriação como o consumo das matérias significantes, e a decodificação de que ele trata, como a produção de sentidos que se dá na leitura e interpretação. Enfim, como já foi posto, não há consenso sobre as noções aqui tratadas, e este artigo, ainda que traga uma proposta incipiente, busca avançar em alguma medida nas distinções entre os conceitos.

\section{Referências}

ABAGNANO, Nicola. USOS. Dicionário de filosofía. Tradução Alfredo Bosi. São Paulo: Martins Fontes, 1998.

BARBOSA, Lívia; CAMPBELL, Colin. O estudo do consumo nas ciências sociais contemporâneas. In: BARBOSA, Lívia; CAMPBELL, Colin. Cultura, consumo e identidade. Rio de Janeiro: Editora FGV, 2009. p. 21-44

CARRASCOZA, João Anzanello; ROCHA, Rose de Melo. Consumo midiático e culturas da convergência. São Paulo: Miró Editorial, 2011.

DE CERTEAU, Michel. A invenção do cotidiano. Petrópolis: Vozes, 2007.

DOUGLAS, Mary; ISHERWOOD, Baron. 0 mundo dos bens: para uma antropologia do consumo. Rio de Janeiro: Editora UFRJ, 2009.

FAIRCHILD, Henry Pratt. CONSUMO. In: FAIRCHILD, Henry Pratt. Diccionario de Sociologia. México-Buenos Aires: Fondo de cultura económica, 1949.

GARCÍA CANCLINI, Néstor. Consumidores e cidadãos. Rio de Janeiro: UFRJ, 2005a.

GARCÍA CANCLINI, Néstor. Culturas híbridas: estratégias para entrar e sair da modernidade. 4. ed. São Paulo: Edusp, 2003.

GARCÍA CANCLINI, Néstor. Cultura sem fronteiras. Caderno de Leitura. EDUSP, [2008]. Disponível em: <http://www.edusp.com.br/cadleitura/cadleitura_0802_8.asp>. Acesso em: $15 / 09 / 2014$ 
GARCÍA CANCLINI, Néstor. El Consumo Cultural: una propuesta teórica. In: SUNKEL, Guilhermo. El consumo cultural en América Latina. Construcción teórica y líneas de investigación. 2ª Ed. ampliada y revisada. Bogotá: Convenio Andrés Belo, 2006. (p. 72-95).

GARCÍA CANCLINI, Néstor.; ROSAS MANTECON, Ana. Políticas culturales y consumo cultural urbano. In: GARCÍA CANCLINI, Néstor (Org.). La antropología urbana en México. Ciudad de México: Conaculta, UAM, FCE, 2005b. (p. 168-195).

HALL, Stuart. Da diáspora: identidades e mediações culturais. Belo Horizonte: Editora UFMG, 2011.

JACKS, Nilda (Org.). Meios e audiências II: a consolidação dos estudos de recepção no Brasil. Porto Alegre: Sulina, 2014.

JACKS, Nilda et al. Meios e audiências: a emergência dos estudos de recepção no Brasil. Porto Alegre: Sulina, 2008.

JACKS, Nilda. Tendências Latino-Americanas nos Estudos de Recepção. Revista FAMECOS, Porto Alegre, v. 5, p. 44-49, 1996.

JACKS, Nilda; ESCOSTEGUY, Ana Carolina. Comunicação e recepção. São Paulo: Hacker Editores, 2005.

LEAL, Ondina Fachel. Etnografia da audiência: uma discussão metodológica. In: Mauro Wilton de Souza. Sujeito, o lado oculto do receptor. São Paulo: Brasiliense, 1995, p.113121.

LOZANO, Elizabeth. Del sujeto cautivo a los consumidores nomádicos. In: Diálogos de la comunicación, Lima, n. 30, 1991.

MARTIN-BARBERO, Jesús. Dos meios às mediações: comunicação, cultura e hegemonia. Rio de Janeiro: Editora UFRJ, 2003.

MARTIN-BARBERO, Jesús. Recepción de medios y consumo cultural: travesías. In: SUNKEL, Guilhermo. El consumo cultural en América Latina. Construcción teórica y líneas de investigación. $2^{\text {a }}$ Ed. ampliada y revisada. Bogotá: Convenio Andrés Belo, 2006. (p. 47-71).

MARTIN-BARBERO, Jesús. REY, Germán. Os exercícios do ver: hegemonia audiovisual e ficção televisiva. São Paulo: Editora Senac, 2001.

MARTIN-BARBERO, Jesús. De la filosofia a la comunicación. Umbral XXI, n. 4, p. 34-39, 1990.

MORA, José Ferrater. USOS. In: MORA, José Ferrater. Diccionario de filosofía. Barcelona: Editora Ariel, 1994. (Tomo IV).

RODRIGUES, Adriano. A gênese do campo dos media. In: SANTANA, Raimundo Nonato.

Reflexões sobre o mundo contemporâneo. Teresina: Revan, 2000. p. 201-221 
RONSINI, Veneza Mayora. A perspectiva das mediações de Jesús Martín-Barbero (ou como sujar as mãos na cozinha da pesquisa empírica de recepção). In: ENCONTRO DA COMPÓS, 19., 2010, Rio de Janeiro. Anais... Rio de Janeiro, 2010.

RONSINI, Veneza Mayora. Mercadores de sentido. Consumo, mídia e identidades juvenis. Porto Alegre: Sulina, 2007.

RONSINI, Veneza Mayora. 0 que falar de consumo e recepção de mídia quer dizer. In: JORNADA GAÚCHA DE PESQUISADORES DA RECEPÇÃO, 1., 2012, Porto Alegre. Anais... Porto Alegre: Observatório Gráfico, 2013.

SCRUTON, Roger. Wittgenstein. Introdução à filosofia moderna. Rio de Janeiro: Zahar, 1982.

SILVERSTONE, Roger. Por que estudar a mídia? São Paulo: Loyola, 2002.

SUNKEL, Guilhermo. Introdución: el consumo cultural en la investigación en comunicacióncultura en la América Latina. In: SUNKEL, Guilhermo. El consumo cultural en América Latina. Construcción teórica y líneas de investigación. 2. ed. Bogotá: Convenio Andrés Belo, 2006. p. $15-46$

TOALDO, Mariângela; JACKS, Nilda. Consumo midiático: uma especificidade do consumo cultural, uma antessala para os estudos de recepção. In: ENCONTRO DA COMPÓS, 22., 2013, Salvador. Anais... Salvador, 2013.

VERÓN, Eliseo. A produção de sentido. São Paulo: Cultrix, 1980. 


\title{
Consumption, senses, uses and appropriations in reception research:
}

\section{Not so close, yet not so far}

\begin{abstract}
The article discusses the approaches and specificities of the meanings of consumption, senses, uses and appropriations, key concepts to the studies of the field called reception, especially the Latin American branch. Furthermore, addressed the differences between reception and media consumption. The proposals of García Canclini and Martín-Barbero are used as a basis, as well as definitions of philosophy and sociology dictionaries. The expected is to contribute to the debate with some meanings, overlaps and contradictions of these terms to present a proposal that distinguishes them as a process of symbolic acquisition of media products.
\end{abstract}

\section{Keywords}

Reception. Media consumption. Use (concept). Sense (concept). Appropriation (concept).

Recebido em 15/09/2015

Aceito em 12/11/2015 